UDC 811.111

DOI https://doi.org/10.32447/2663-340X-2019-6-8

\title{
DIFFERENT SYMBOLS IN STEPHEN KING'S NOVELS: A LINGUOPOETIC ASPECT
}

\author{
Didukh Lyubov Ivanivna \\ PhD in Pedagogy \\ Associate Professor at the Department of Foreign Languages and Translation Studies \\ Lviv State University of Life Safety \\ Kleparivska Street, 35, Lviv, Ukraine
}

\begin{abstract}
This article deals with special symbols in Stephen King's novels. It is proved that symbols have always been deeply investigated in Poetics and Text Linguistics; they play an important role in any text; both in ancient and in modern texts many colour, number, animal or graphical images can be found as different symbols. It's also defined that universal symbols are easily recognizable and that's why remain in the reader's memory. Writers often use symbolic images in their literary works, sometimes very overtly, sometime more implicitly. The article also focuses on the fact that $S$. King uses plenty of symbols and word images to convey some important messages for his readers, to scare them even more or to tell a story of his life. Some examples of these symbols like special animals, colours, numbers, graphical images are discussed in our research. The author states that one of the key themes of his works is the motif of alcoholism or the strength of addiction which can be presented by many symbols, for example the dog's rabies. The article also deals with the symbolic nature of S. King's characters, as they are also very similar to the author himself - they are teachers or writers, they try to be good husbands and fathers, have problems with alcohol or find themselves in situations in which the author had been too. It's proved that $S$. King's symbolism is immensely meaningful and is an important part of the story.
\end{abstract}

Key words: symbols, graphical images, Stephen King's novels, horror genre, fear.

Introduction. According to the Cambridge Dictionary, a symbol is 'a sign, shape, or object that is used to represent something else' [7]. This definition shows that people created symbols in order to convey some meaning in a different way, usually non-verbal. Although some people might not be aware of it, symbols surround us in everyday life. They may be easy noticed on the road signs, as national emblems, in public transport, in restaurants or even in the social media. Most people recognise these symbols and understand their meaning, because they are of universal nature and have an international use. Nowadays a symbol can be verbal or non-verbal, that is a picture, a word, a group of words, a sign or an object.

Theoretical framework. Symbols have always been an extremely important part of Poetics. Word images can be found mainly in mythology and the Bible. Although both of these works are really old, they used lots of symbols to convey some important thoughts. Understanding these symbolical works was at that time very important. Many phrases used in mythology are present in today's language, for example 'the Gordian knot', 'apple of discord' or 'Achilles' Heel'. Those phrases have some hidden meaning which is known for most of people. Biblical expressions such as 'the garden of Edem' or 'forbidden fruit' are also commonly used in modern language as a symbol of paradise or something that is not allowed. Examples given above show that symbols have always played an important role in literature and Poetics.

Classification of images is very diverse. Actually, a good writer can make an interesting symbol out of anything. Often, a symbol is a colour, a number, a name or an animal. However, many well-known symbols are characters, for example is mythology: greek gods always depicted something special. Apollo was the god of archery, Nike was a goddess of victory and Athena depicted wisdom and war. Mythology is the greatest example of giving characters symbolical meaning, but other examples can be found in the Bible and in modern literature. Many modern writers use symbols in their works too. A great example could be Dan Brown, who wrote a novel The da Vinci Code and other interesting novels, which are brimful of symbols that constitute a huge part of their plot.

Colours can also be a powerful image. It is proved that colours affect our mood, so writers can use them to convey some hidden meaning. Such symbols can be found even in children tales. 'Little Red Riding Hood' is just one of the examples. Although children may not understand the meaning of these colours, they stay in their minds as an association with some concrete character or event described in the fairy tale. The Bible also contains many symbolical colours, for example white which is the colour of angels depicting sacredness and chastity.

The Bible also gives some symbolical numbers. One of the most recognizable is 666, which is often associated with the devil or demons. Numbers 3, 7, 10 and 12 in the Bible depict completeness. Number 50 is important too, as it is connected with the holy day of Pentecost. What is more, numbers were also significant for philosophers, such as Plato or Pythagoras, but they are no less important nowadays. Many 
people believe that numbers, just like colours, can really impact upon their life. This is why numbers are a great and widely used type of symbols.

Other writers used animals as symbols of huan features or other important images. Animals such as a lion, a vulture, a donkey or an owl are used nowadays to describe different types of people. Hemingway, Orwell and many other writers used animals in their works. They also play a major role in fairy tales. 'Animal fables and beast fairy tales are found in ancient Egypt and Greece and India, and the legendary Aesop of the classics has his storytelling counterparts all over the world, who use crows and ants, lions and monkeys, ravens and donkeys to satirise the follies and vices of human beings and display along the way the effervescent cunning and high spirits of the fairytale genre'[6].Many stories also involve imaginary animals, such as unicorns and beasts. The importance of animal symbols in literature cannot be neglected.

One more group of symbols often used by writers are graphical icons created for the purpose of a literary work. A very well-known example comes from The Harry Potter series.

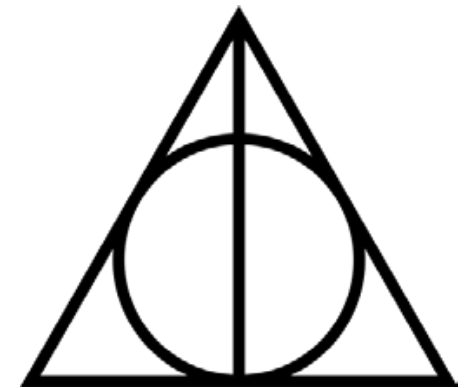

Pic. 2. Sign of the Deathly Hallows
It's interesting to know that this symbol was created especially for this popular book series and depicts three powerful objects: the Elder Wand, the Resurrection Stone and the Cloak of Invisibility. The image has become so popular that many people decided to tattoo it. Another popular graphical symbol is the Tolkien's symbol connected with the runes of the Ring. The novel "The Lord of the Ring" is full of symbolism, but the runes of the Ring are so recognizable, that people engrave it on their wedding rings. This also shows what a huge impact literary symbols can have on readers.

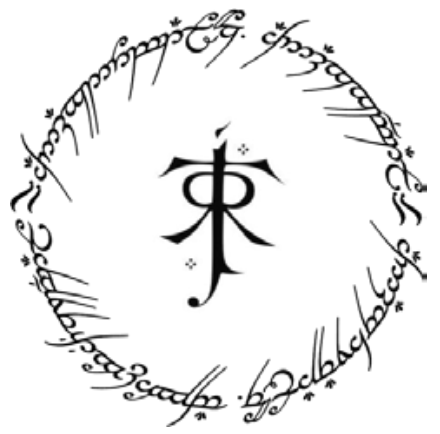

Pic. 3. The Runes of the Ring and the Tolkien's Symbol

The aim of the study is to investigate the poetic role of symbols in Stephen King's novels. In this article the object is different symbols and the verbal means of their presenting that Stephen King used in his novels.

Among the main tasks of our research are the following: to analyse types of symbols used by Stephen King and their meaning in the novels under analysis.

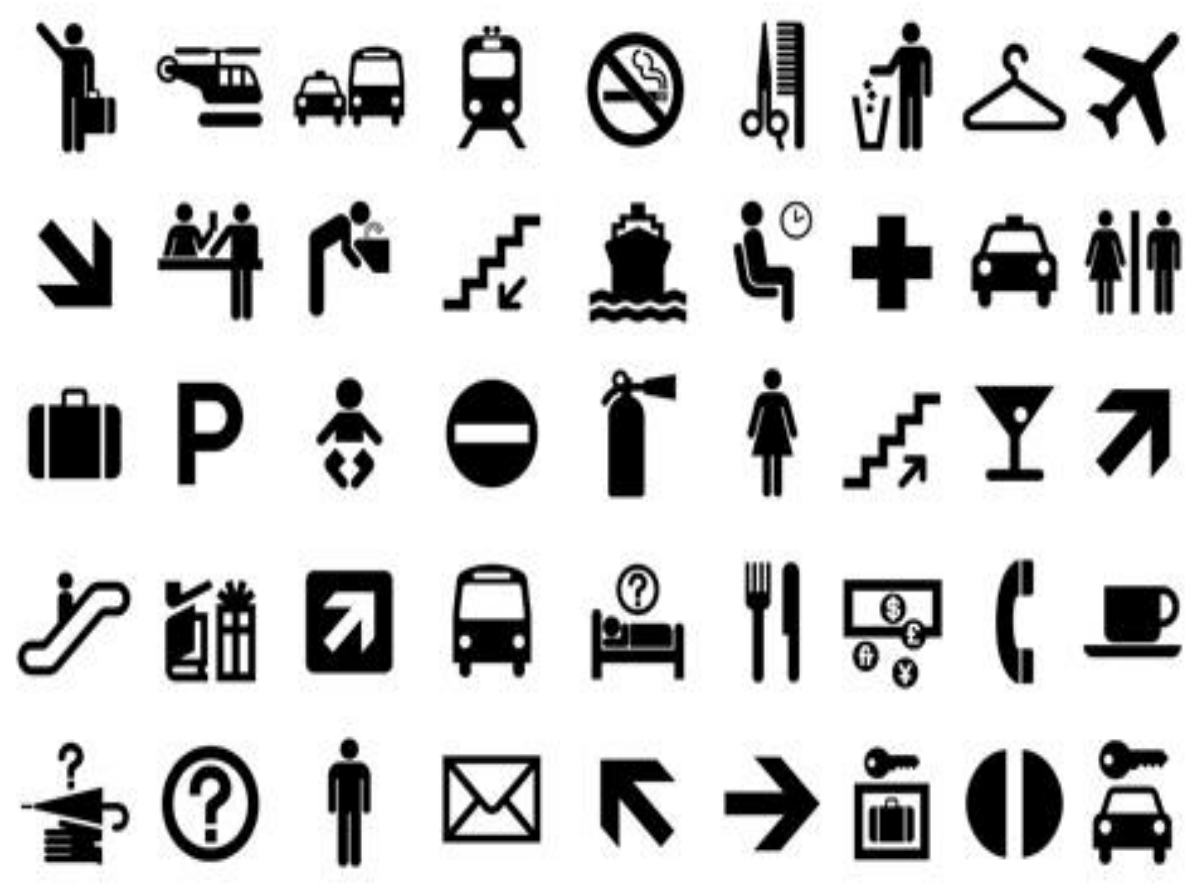

Pic. 1. Universal Symbols 
Research findings. The horror genre is strongly connected with symbolism. It is based on symbols that depict fear. A ghost, a vampire, a monster - all of them are symbolic figures of danger. In the gothic literature a building was often a symbol of immuring and the inability to set free. A gothic heroine symbolized weakness, and the man who saved her represented strength and bravery. S. King, however, has introduced some novelty to symbolism in the field of horror genre.

S. King admits that symbols are very importan for his stories. In Danse Macabre he wrote that 'a horror story - no matter how primitive, in its nature constitutes a kind of an allegory. In other words, it is symbolic ... Horror attracts us because in a symbolical way it articulates things that we fear of in a direct way' [translation mine] [1, 59-60].

At first, S. King uses many repeatable themes in his works that can work as symbols very well. Usually, these motifs represent his personal experience and history. One of the most recurring themes is a small American town in Maine, where the author lives. The narrative of King's stories does not only give a fictional name of the town, but it also provides details about its streets, shops, landscape, inhabitants and history. The best example here is Derry, appearing among others in It. Although the town does not exist in the real world, S. King created an image of it that was extremely precise and full of detail. What is more, many places in this fictional town also had a symbolical meaning, for example the Black Spot became a symbol of a tragedy for the whole town.

Another motif that can be noticed in many of S. King's stories is alcohol addiction. It can be found for example in The Shining, when Jack Torrance does what his son calls 'the Bad Thing'; in Cujo, where Joe Camber drinks alcohol until he gets killed by a rabid dog; or in Doctor Sleep, where adult Danny Torrance tries to 'shed his father's legacy of despair, alcoholism and violence' [10]. This theme is also strongly connected with the author's private life. For many years S. King was addicted to alcohol, although he did not want to admit that. "'Damn it! I'm an alcoholic!," I thought and there was no voice of protest in my head. Eventually, I was the one who wrote The Shining without even realizing (at least until that day) I was writing about myself' 'translation mine] [2, 79]. In On Writing the author openly admits what an awful disease alcoholism is and how difficult it was to fight it. Using motifs connected with alcohol in his novels is a symbol of his own struggle against addiction.

Some other motifs appearing in more than one of S. King's stories are: child abuse, marital problems and child or teenage characters as protagonists. It is not confirmed that all of these themes come from the author's private life, yet many of them do stand as symbols for something important.

S. King uses many other types of symbols. Animal images constitute an important part of the author's symbolism. When S. King gave the list of 10 of the scariest things, 3 of them concerned animals: the fear of snakes, the fear of rats and the fear of insects, especially spiders, flies and beetles [3]. It is apparent then that S. King thinks that animals can depict fear and danger or strong disgust.

An example of animal symbol is the wasps' nest from The Shining. A separate part of this novel is entitled 'The Wasps' Nest' describing an odd experience in the Overlook Hotel. When Jack Torrance found the nest on the roof, he ascertained that 'those were the big ones, the vicious ones, which build their nests in the walls, not the smaller and mild ones, which were yellow' [translation mine] [4, 126].

This is already where the author starts to introduce one of the 'ten bears' that scare the readers the most. Most of people who imagine big, mean wasps, already feel disgust and fear. In this story, however, the wasps are special. Before being stung and attempting to kill the insects, Jack spends nearly half an hour analysing his past. He dwells upon the moment of breaking his son's arm, his outbursts of anger, his childhood full of struggles and fear of his father. Finally, the main character of the novel came to the conclusion: ' $\mathrm{He}$ got the impression as if he accidentally put his hand into a huge wasps' nest of life. It was a poor metaphor, but in his estimation it was quite a good picture of the state of things' [translation mine] [4, 128-129]. Jack tried to justify his behaviour, just like a child who is stung by wasps and nobody expects it to be happy at the moment.

Another type of images used by S. King are numbers. Although there are not many examples that can be found in his works, there is one number that seems to be the most important for all of King's fertileness that's the number 19. It appears mainly in The Dark Tower series. In this novel series the number often occurs in a direct way. In other cases, a clever reader has to find it in many details of S. King's novels. For example, in The Shining we can read: 'There were nineteen steps down to the lobby. She had counted them enough times to know. Nineteen carpeted stair risers, and nary a Jack crouching on any one of them' [8]. What is more, Jack Torrance 'is an ill-mannered but well-meaning alcoholic nineteen months into sobriety' [5]. The most often mentioned and the most dangerous place in the Overlook Hotel is room 217, while $2+17=19$. In many other novels different numbers added together give number 19. This number probably has a special meaning for the author. One of the most terrible things in his life happened on 19 June 1999 - he was hit by a truck and he almost died $[2,201]$. The meaning of the number is symbolical for sure, yet every reader needs to try to understand it himself.

Apparently, number 7 is also important in S. King's works. In general, 7 is often assumed to be a lucky or a complete number. The Dark Tower series consists of 7 books. There were 7 of the kids in It, and only in this number they were able to fight It. Number 7 in S. King's novels stands for completeness indeed.

Colour images are also very important in S. King's novels, for they can also present different meanings. 
For example, in his most popular book series entitled The Dark Tower. This piece of art in the science-fiction genre (which also includes horror) gives examples of many colours depicting different things. All of the 13 colours occurring there create the Wizard's Rainbow. Colours such as black, pink, orange, purple, yellow, green, blue, crimson, indigo, azure or grey can be identified in it. Each of them is attached to a special meaning. For example, the Black Bend, also called the Black Thirteen, is the symbol of evil forces, for it is used by the story's main antagonist, the Crimson King, 'to monitor the events of MidWorld' [9]. Other colours represented luck, telepathy, love, power, courage, purity and other important elements of the story. S. King also created an antagonist called the Crimson King, and the two opposite powers called the Red and the White. It is obvious then that S. King attaches great importance to colour images.

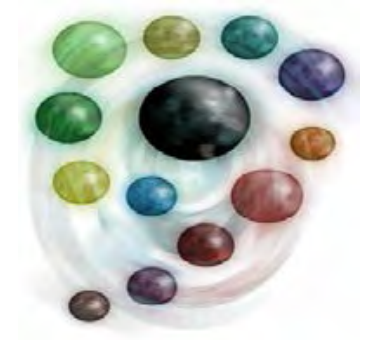

Pic. 4. Maerlyn's Rainbow

However, the Dark Tower series is not the only work in which S. King used colour symbolism. He also wrote a short novella entitled Low Men in Yellow Coats. The main character claims that 'he is being stalked by "low men" who work for The Crimson King' [10]. Yellow coats, therefore, depict evil forces, almost like the crimson colour. In It little Georgie was also wearing a yellow coat the day he died. The yellow colour appears quite often in S. King's works, although it may not be strongly highlighted. The author uses many yellowish adjectives to describe the atmosphere changing. Obviously, this colour in his works stands as a symbol of danger, evil, and sometimes even death.

S. King also uses some graphical symbols in his works, mainly in The Dark Tower. Such symbols in literature are usually fictional, created for the needs of a concrete story. In S. King's most popular novel series few of them can be found. One of the examples is the symbol of the Crimson King's Eye:

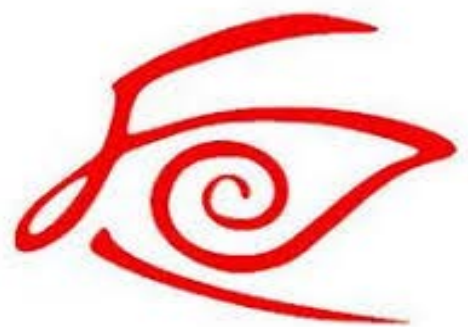

Pic.5. The Crimson King's Sigil

The symbol can be found in correlation with the words 'ALL HAIL THE CRIMSON KING!'. Other graphical symbols that can be found in S. King's works are the Ka symbol in The Dark Tower or the symbol on the door of Pennywise from It. Although all of these symbols are imaginary and have the meaning given by the author himself, the readers all over the world tattoo them and make them something important in their lives.

Many other symbolical themes can be found in S. King's works, and every reader, every critic can interpret them in his or her own way. However, every book written by S. King does have some deeper meaning, and the reader's goal is to discover it in his own line of reasoning.

Conclusions. Symbols are an inseparable part of the horror genre, and the modern master of this genre makes great use of them. S. King's symbols are varied, but all of them are interesting and worth considering. Many types of symbols used in the analysed novels are: animal, colour, number, character and graphical images as well as recurring themes, motifs and references to his personal experiences. S. King has also explained his way of creating or highlighting symbols found in his works and stressed the importance of symbolism in literature. Many topics that occur in his stories depict his personal fears or are strongly connected with his life, which is the novelty in the linguistic field.

Horror is a genre that is based on human imagination, so individual perception of the themes, symbols and motifs occurring in S. King's stories is the key to understanding his work. Thus, the perspective of further research is to study the interpretation of different Stephen King's symbols.

\section{ЛITEPATУРA}

1. King, S., 1995. Danse Macabre. Warsaw, Prószyński i S-ka.

2. King, S., 2001. Jak pisać: Pamiętnik rzemieślnika. Warsaw, Prószyński i S-ka.

3. King, S., 1986. The Horror Writer and The Ten Bears. [in:] Miller C. \& Underwood T. (ed.), Kingdom of Fear: The World of Stephen King (p. 10). Falmouth, Hodder \& Stoughton.

4. King, S., 1998. The Shining. Warsaw, Prószyński i S-ka. p. 126.

5. Oncken, L., 2016. Summer Reading: Here's Johnny's Addiction. Retrieved April 3, 2019, from www.newamerica.org.

6. Warner, M., 2009. Animals in fairytales. Retrieved March 25, 2019, from www.theguardian.com.

7. Retrieved April 2, 2019, from www.dictionary.cambridge.org.

8. Retrieved April 3, 2019, from www.novels9.com.

9. Retrieved April 3, 2019, from www.darktower.fandom.com.

10. Retrieved April 3, 2019, from www.stephenking.fandom.com. 
1. King, S., 1995. Danse Macabre. Warsaw, Prószyński i S-ka.

2. King, S., 2001. Jak pisać: Pamiętnik rzemieślnika. Warsaw, Prószyński i S-ka.

3. King, S., 1986. The Horror Writer and The Ten Bears. [in:] Miller C. \& Underwood T. (ed.), Kingdom of Fear: The World of Stephen King (p. 10). Falmouth, Hodder \& Stoughton.

4. King, S., 1998. The Shining. Warsaw, Prószyński i S-ka. p. 126.

5. Oncken, L., 2016. Summer Reading: Here's Johnny's Addiction. Retrieved April 3, 2019, from www.newamerica.org.

6. Warner, M., 2009. Animals in fairytales. Retrieved March 25, 2019, from www.theguardian.com.

7. Retrieved April 2, 2019, from www.dictionary.cambridge.org.

8. Retrieved April 3, 2019, from www.novels9.com.

9. Retrieved April 3, 2019, from www.darktower.fandom.com.

10. Retrieved April 3, 2019, from www.stephenking.fandom.com.

\title{
ILLUSTRATIVE SOURCES:
}

1. Universal Symbols [Electronic Resource]. - Access Mode : http://125.pratt.edu/gallery/artist/cook.

2. Sign of the Deathly Hallows[Electronic Resource]. - Access Mode https://pl.wikipedia.org/wiki/Plik:Sign_of_ the_Deathly_Hallows.svg.

3. The Runes of the Ring and the Tolkien's Symbol[Electronic Resource]. - Access Mode : https://www.pinterest.at/ $\operatorname{pin} / 836191855787579409 /$.

4. Maerlyn's Rainbow[Electronic Resource]. - Access Mode :https://darktower.fandom.com/wiki/Maerlyn\%27s_ Rainbow.

5. The Crimson King's Sigil[Electronic Resource].-Access Mode :https://pl.pinterest.com/pin/531565562244791595.

\section{РІЗНОМАНІТНІ СИМВОЛИ У РОМАНАХ СТІВЕНА КІНГА: ЛІНГВОПОЕТИЧНИЙ АСПЕКТ}

\author{
Дідух Любов Іванівна \\ кандидат педагогічних наук, \\ дочент кафедри іноземних мов та перекладознавства \\ Львівського державного університету безпеки життєдіяльності \\ вул. Клепарівська, 35, Львів, Україна
}

У иій статті йдеться про особливі символи в романах Стівена Кінга. Доведено, щзо символи завжди були глибоко досліджені в поетиці та мовному тексті; вони відіграють важливу роль у будь-якому тексті; $i$ в давніх, $i$ в сучасних текстах можна віднайти багато символів кольору, числа, тварин або графічних зображень. Також визначено, щу універсальні символи легко розпізнаються, і тому залишаються в пам'яті читача. Письменники часто використовують символічні образи у свої літературних творах, іноді дуже відверто, а іноді - навпаки. У статті також акцентується увага на тому, що С. Кінг використовує безліч символів та зображень слів, щчоб передати важливі повідомлення для своӥх читачів, щьоб щее більше їх налякати чи розповісти історію свого життя. Деякі приклади таких символів, як особливі тварини, кольори, иифрии, графічні зображення, обговорюються в нашому дослідженні. Автор заявляє, що однією з ключових тем його творів є мотив алкоголізму чи сила залежності, яку можна представити багатьма символами, наприклад сказом собаки. У статті також розглядається символічний характер персонажів С. Кінга, оскільки вони також дуже схожі на самого автора - вони вчителі чи письменники, намагаються бути добрими чоловіками та батьками, мають проблеми з алкоголем або опиняються в ситуаціях, у який автор сам побував. Доведено, щчо символіка С. Кінга надзвичайно значуща $і \epsilon$ важливою частиною історії.

Ключові слова: символи, графічні зображення, романи Стівена Кінга, жанр жахів, страх. 